\title{
Biodegradation of Crude Oil Through Biosurfactant Producing Bacterial Strains Isolated from Oily Sludge
}

\author{
Veeranna Channashettar ${ }^{1,2}$, Shaili Srivastava ${ }^{2 *}$ and Banwari Lal ${ }^{1}$ \\ ${ }^{1}$ Amity School of Earth and Environmental Sciences, Amity University, Gurgaon, \\ Haryana, India \\ ${ }^{2}$ Environmental and Industrial Biotechnology Division, The Enrgy and Resources \\ Institute (TERI), New Delhi, India \\ *Corresponding Author: Shaili Srivastava, Amity School of Earth and \\ Environmental Sciences, Amity University, Gurgaon, Haryana, India.
}

DOI: $10.31080 /$ ASMI.2020.03.0509
Received: January 24, 2020

Published: February 08, 2020

(C) All rights are reserved by Shaili

Srivastava., et al.

\section{Abstract}

The biodegradation of crude oil through biosurfactant produced by bacteria isolated from oily sludge collected from contaminated sites of three different refineries were studied. Eight bacterial isolates were screened for biosurfactant production by serial dilution technique and spread plate method. Two bacterial isolates were found capable of producing significant quantity of biosurfactant exhibited by surface tension activity ( $26.66 \mathrm{dy} / \mathrm{cm}$ ), emulsification activity (up to 79\%) and total petroleum hydrocarbon reduction (up to $92 \%$ ). Gas chromatography analysis of 5 days treated MSM containing 1\% crude oil as sole source of carbon and energy showed decrease in the concentration of aliphatic and aromatic hydrocarbon present in crude oil. The degradation of aliphatic and aromatic compounds of crude oil clearly indicates the production of biosurfactant by both bacterial isolates (TER-4 and TER-7). Keywords: Biodegradation; Crude Oil; Biosurfactant; Isolate; Oily Sludge

\section{Introduction}

Oily sludge is a major hazardous waste encountered in oil refining operations, which causes enormous environmental pollution. The hazardous oily waste is composed of total petroleum hydrocarbons (TPH), water, and sediments. The TPH constitutes a complex mixture of alkane; aromatic; nitrogen, sulfur, and oxygen containing compounds (NSO); and asphaltene fractions [1] None of the available conventional disposal methods are environment friendly. Biological methods have been well reviewed and acknowledged for remediation of hydrocarbon waste [2]. Bioremadiation is an efficient, economic and eco-friendly alternative to physical and chemical remedial option.

Bioremediation is a process that uses naturally occurring microorganisms to transform harmful substances to non-toxic compounds. There are innumerable strains of microbes under basic categories of bacteria, yeast or fungi, which degrade oily sludge through digestion of harmful chemicals and compounds present in oily sludge into simpler, less toxic or non-toxic substances. Microorganisms, like all living organisms, need nutrients (such as nitrogen, phosphate, and trace metals), carbon and energy to survive. These beneficial microbes break down a wide variety of organic (carbon-containing) compounds found in oily sludge to obtain energy for their growth. Many species of soil bacteria, for example, use petroleum hydrocarbons as a food/energy source, transforming them into harmless substances consisting mainly of carbon di- oxide, water and fatty acids. Bioremediation employs this natural process by promoting the growth of microbes that can effectively degrade specific contaminants and convert them to nontoxic byproducts.

Production of biosurfactant by bacteria is considered an important microbial strategy that influence the bioavailability of hydrophobic chemicals by changing the surface properties of bacterial cell or by dissolving and emulsifying hydrophobic hydrocarbons [3]. Biosurfactants are of increasing interest for commercial use because of the continually growing spectrum of available substances. There are many advantages of biosurfactants compared to their chemically synthesized counterpart. Unlike synthetic surfactants microbial-produced compounds are easily degraded [4] and particularly suited for environmental applications such as bioremediation and dispersion of oil spills [5]. Biosurfactants have been tested in environmental applications such as bioremediation and dispersion of oil spills, enhanced oil recovery and transfer of crude oil. Usually the microorganisms capable of utilizing aromatic and aliphatic hydrophobic compounds produce biosurfactant. On the other hand, catabolism of alkane and aromatic compound is not a prerequisite for biosurfactant production in all bacteria.

The present study aimed to isolate, characterize biosurfactant producing bacterial strain and explore the opportunity to utilize for bioremediation of oil contaminated soil. 


\section{Materials and Methods}

\section{Soil sample collection}

Oily sludge samples were collected from oil refineries viz. Indian Oil Corporation Ltd. (IOCL), Panipat, Haryana, IOCL., Mathura, UP and Hindustan Petro Chemical Ltd., Mumbai, Maharastra from 10 different sites of each refinery in sterile glass containers and stored at $4-5^{\circ} \mathrm{C}$ for further study.

\section{Enrichment and isolation of bacteria}

The bacterial strain capable of degrading oil were isolated from oily sludge by enrichment technique and serial dilution technique. The minimal salt medium (MSM) was prepared by adopting composition as described by Lal and Khanna [6]. The media was sterilized for 15 minutes by autoclaving at $121^{\circ} \mathrm{C}$ at $15 \mathrm{lb}$ pressure. The cultures were grown in $250 \mathrm{ml}$ conical flask containing 100 $\mathrm{ml}$ sterile medium at $37^{\circ} \mathrm{C}$ and $150 \mathrm{rpm}$. For enrichment, $10 \mathrm{~g}$ oily sludge sample collected from oil contaminated sites of refineries were inoculated into $90 \mathrm{ml}$ of MSM containing sterilized crude oil $(1.0 \%, \mathrm{w} / \mathrm{v})$ as carbon source and incubated at $37^{\circ} \mathrm{C}$ on a rotary shaker (150 rpm) for 5 days. Based on the cell growth in enriched culture, three cycles of re-inoculation in fresh MSM with $5 \mathrm{ml}$ of enriched culture were repeated under similar conditions to ensure the utilization of crude oil as carbon source. After that, $1 \mathrm{ml}$ of growth culture was diluted by serial dilution technique up to 109 fold. $100 \mu \mathrm{L}$ of all dilutions were plated on MSM agar plates with crude oil $(1.0 \% \mathrm{w} / \mathrm{v})$ and were incubated at $37^{\circ} \mathrm{C}$. After an incubation period of $72 \mathrm{~h}$, the bacterial colonies obtained were further purified on the MSM agar plates (with crude oil 1.0\% w/v).

The bacterial strains that could degrade total petroleum hydrocarbons were maintained on MSM agar plates with crude oil $1.0 \%$ v/v). Frozen stock cultures were stored in $25 \%$ glycerol at $-70^{\circ} \mathrm{C}$. Cultures were sub-cultured at an interval of 15 days. The glycerol stocks of all the bacterial strains were thawed and streaked over MSM containing crude oil $(1.0 \% \mathrm{v} / \mathrm{v})$. The plates were incubated at $37^{\circ} \mathrm{C}$. Liquid cultures of bacterial strains required for degradation studies were grown at $37^{\circ} \mathrm{C}$ for $72 \mathrm{~h}$ in $5 \mathrm{ml}$ MSM with $1.0 \%(\mathrm{w} / \mathrm{v}$ ) sterilized crude oil. For biochemical characterization, the bacterial strains were grown either on Luria Bertani broth (LB) or Luria Bertani agar (LA) plates.

Characterization, screening and biodegradation study of biosurfactant producing bacterial strains

The surface tension was measured by following the De Nöuy platinum ring method described by Bodour and Miller-Maier [7]. Emulsification activity (E24) was measured by following the method described by Cooper and Goldenberg [8]. Residual crude oil was extracted from the media by using solvent extraction method (USEPA 9071B) using Soxhlet extractor and the amount of TPH recovered was quantified by gravimetric method [9].
Total Petroleum Hydrocarbon (TPH) extracted from biosurfactant producing isolates was fractionated into aliphatic hydrocarbons and poly-aromatic hydrocarbons by silica gel column, eluting with hexane followed by toluene [10]. Both hexane and toluene fractions were dried completely on a rotary evaporator, and by simple gravimetric method, the weight of the eluted alkane and aromatic fractions were calculated. Fractions eluted from the column with hexane and toluene were analyzed by GC (Hewlett Packard 5890 Series II) fitted with FID (flame ionization detector) and DB-2887 column (30 m $90.22 \mathrm{~mm}$ id and $2.64 \mathrm{ml}$ film thickness). The operating conditions used for hexane fraction are as follows: injector and detector temperature $300{ }^{\circ} \mathrm{C}$; oven temperature was programmed as follows: $80{ }^{\circ} \mathrm{C}$ for $1 \mathrm{~min} @ 15{ }^{\circ} \mathrm{C} \min -1$ to $220{ }^{\circ} \mathrm{C}$. Helium was used as a carrier gas with a flow rate of $2.5 \mathrm{ml} \mathrm{min}-1$ (total run time $63.0 \mathrm{~min}$ ). The aromatic hydrocarbons were analyzed on a DB-23 column (30 m $90.20 \mathrm{~mm} 92.64 \mathrm{ml}$ film thickness) with operating parameter: injector and detector temperature 300 ${ }^{\circ} \mathrm{C}$; oven temperature $60^{\circ} \mathrm{C}$ for $1.0 \mathrm{~min} @ 8^{\circ} \mathrm{C} / \mathrm{min}$ to $280^{\circ} \mathrm{C}$ for 20.0 $\mathrm{min}$. Helium was used as a carrier gas at a flow rate $1.1 \mathrm{ml} / \mathrm{min}$. The percent decrease in the peak areas of the different hydrocarbons relative to the controls was adopted as a measure of hydrocarbon degradation mentioned [9].

\section{Results}

The oily sludge samples collected from three different oil refineries were enriched with $1 \%$ crude oil as a sole carbon and energy source in MSM media to allow the bacteria present in oily sludge to degrade the crude oil (Figure 1). The turbidity due to growth of bacteria was observed in enriched media. The turbidity indicated that isolates were capable of utilization of crude oil as sole carbon and energy source and able to degrade the crude oil.

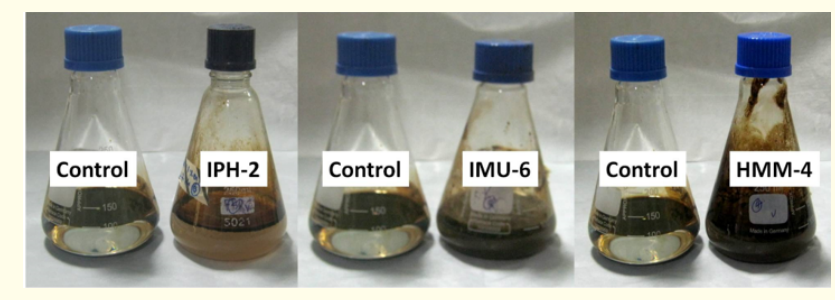

Figure 1: Enrichment of soil samples with crude oil for isolation of oil degrading bacteria. (IPH- IOCL, Panipat, Haryana; IMU-IOCL, Mathura, UP and HMM- HPCL, Mumbai Maharastra).

Based on the turbidity of culture grown in conical flask, the culturable bacterial strains isolated from all the oily sludge samples were isolated and purified by serial dilution technique, spread palate technique in sterilized MSM liquid /solid media enriched with $1 \%$ crude oil as sole carbon and energy source in petri plate (Figure 2 ). The growth of bacterial strains were observed after 5 days of in- 
cubation at $37^{\circ} \mathrm{C}$. The clear zone observed in petri plates indicated that isolates of bacterial strains were capable of degrading crude oil. Eight bacterial isolated strains capable in oil degradation were preserved as frozen stock cultures in $25 \%$ glycerol at $-70{ }^{\circ} \mathrm{C}$ for further experiments. All the bacterial strains were given an accession number as TER-1, TER-2, TER-3, TER-4, TER-5, TER-6, TER-7 and TER-8.

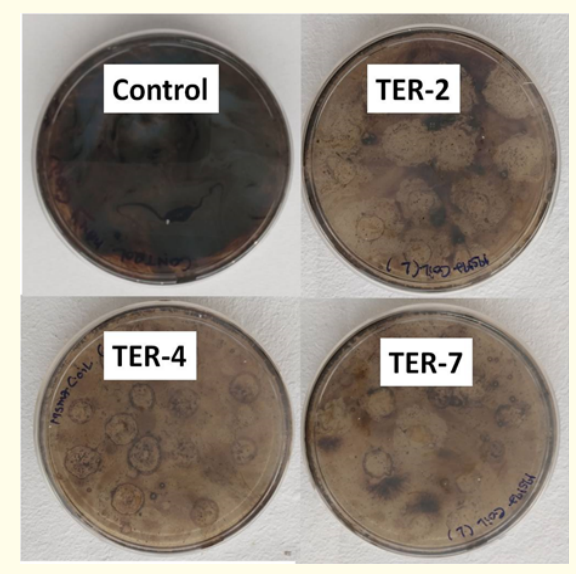

Figure 2: Bacterial isolates grown on crude oil plates

(IPH- IOCL, Panipat, Haryana; IMU-IOCL, Mathura, UP and HMM- HPCL, Mumbai Maharastra).

All the bacterial strains that have been isolated were analyzed for its efficiency of biosurfactant production by studying the surface tension activity, emulsification activity and total petroleum hydrocarbon (TPH) reduction of culture grown in MSM media containing $1 \%$ crude oil as sole carbon and energy source. The isolated bacterial strains were grwon in MSM liquide media in triplicate and supernatent of grown cultures were colected after incubation of 72 $\mathrm{h}$ at $37^{\circ} \mathrm{C}$. The surface tension and emulsification activity of supernatent solutions were recorded (Table 1). The maximum reduction in surface tension was observed in the supernatant solution of isolate TER-7 (26.66 dy/cm) grown in MSM media followed by TER$4(30.33 \mathrm{dy} / \mathrm{cm})$ and minimum reduction in surface tension was observed in the supernatant solution of isolate TER-6 (58.66 dy/ $\mathrm{cm}$ ). The highest emulsification activity (E24) was recorded in the supernatant solution of isolate TER-7 (79.00\%) followed by TER-4 (70.33\%) and minimum E24 activity was found in the supernatant solution of isolate TER-6 (23.00\%). Total petroleum hydrocarbon studies with isolated bacterial strains were performed in $250 \mathrm{ml}$ conical flask containing $100 \mathrm{ml}$ of sterilized MSM media with $1 \%$ $(\mathrm{w} / \mathrm{v})$ of crude oil as sole carbon source in triplicate and incubated on a rotary shaker at $150 \mathrm{rpm}$ and $37^{\circ} \mathrm{C}$. The isolates were grown in standardized MSM for 5 days and were inoculated into the medium with $5 \%(\mathrm{v} / \mathrm{v})$ as inoculum. Uninoculated controls were kept to monitor natural weathering of crude oil. Residual crude oil was extracted from the media by using solvent extraction method (USEPA 9071B) using Soxhlet extractor and the amount of Total Petroleum Hydrocarbon (TPH) recovered was quantified by gravimetric method. The maximum TPH reduction was observed by the isolate TER-4 (92.00\%) followed by TER-7 (90.66\%) and minimum reduction was found by isolate TER-1. The results of surface tension, E24 activity and TPH reduction showed that TER-4 and TER-7 isolates were capable in production of sufficient quantity of biosurfactant to degrade significant quntity of oil. It was found that out of 8 isolates only 2 isolates of bacterial strains were observed capable to degrade the crude oil and selected for further degradation study i.e. TER 4 and TER-7.

\begin{tabular}{|l|c|c|c|}
\hline Isolate & $\begin{array}{c}\text { Surface Tension } \\
(\mathbf{D y} / \mathbf{C m})\end{array}$ & $\begin{array}{c}\text { Emulsification } \\
\text { Activity (E24) (\%) }\end{array}$ & $\begin{array}{c}\text { TPH Reduction } \\
(\%)\end{array}$ \\
\hline TER-1 & $58.33 \pm 1.15^{\mathrm{a}}$ & $24.66 \pm 0.57^{\mathrm{de}}$ & $50.66 \pm 1.52^{\mathrm{f}}$ \\
\hline TER-2 & $45.00 \pm 1.00^{\mathrm{c}}$ & $26.66 \pm 3.21^{\mathrm{de}}$ & $60.00 \pm 2.00^{\mathrm{d}}$ \\
\hline TER-3 & $55.33 \pm 3.78^{\mathrm{a}}$ & $23.66 \pm 1.52^{\mathrm{de}}$ & $56.33 \pm 1.52^{\mathrm{e}}$ \\
\hline TER-4 & $30.33 \pm 1.15^{\mathrm{d}}$ & $70.33 \pm 1.52^{\mathrm{b}}$ & $92.00 \pm 2.00^{\mathrm{a}}$ \\
\hline TER-5 & $49.00 \pm 1.00^{\mathrm{bc}}$ & $29.33 \pm 2.08^{\mathrm{c}}$ & $61.33 \pm 1.52^{\mathrm{cd}}$ \\
\hline TER-6 & $58.66 \pm 3.51^{\mathrm{a}}$ & $23.00 \pm 2.64^{\mathrm{e}}$ & $69.66 \pm 1.52^{\mathrm{b}}$ \\
\hline TER-7 & $26.66 \pm 2.51^{\mathrm{d}}$ & $79.00 \pm 2.00^{\mathrm{a}}$ & $90.66 \pm 2.08^{\mathrm{a}}$ \\
\hline TER-8 & $51.00 \pm 3.00^{\mathrm{a}}$ & $27.33 \pm 1.52^{\mathrm{cd}}$ & $64.33 \pm 3.05^{\mathrm{c}}$ \\
\hline
\end{tabular}

Table 1: Surface tension, emulsification activity and total petroleum hydrocarbon reduction of different isolates (Mean \pm SD, column not followed by same letter are significantly different at $\mathrm{p} \leq 0.05$ using Duncan's multiple range test).

The aliphatic and aromatic hydrocarbons present in the crude oil separated before bioremediation and after 5 days of treatment with bacterial strain TER-4 and TER-7 isolated from oily sludge by column chromatography eluting with hexane followed by toluene. These fractions were analyzed by GC. The GC chromatograph of hexane fraction of 0 day sample showed the presence of aliphatic hydrocarbons from C11 to C37 (Figure 3A). The same sample analyzed after 5 days of treatment with bacterial strain TER-4 (Figure 3B) and TER-7 (Figure 3C) showed reduced concentration of aliphatic hydrocarbons.

Similarly analysis of zero day treated sample of the toluene fraction showed the presence of aromatic hydrocarbons namely napthelene, acenapthylene, acenapthene, fluorine, phenanthrene, anthracene, flouranthrene, benzo(a)anthracene, bnzo (k) fluoranthene and dibenzo (a,h) anthracene (Figure 4A), whereas the treated sample analyzed after 5 days of treatment with bacterial strain TER-4 (Figure 4B) and TER-7 (Figure 4C) showed significant degradation of aromatic hydrocarbons by biosurfactant producing isolates. 


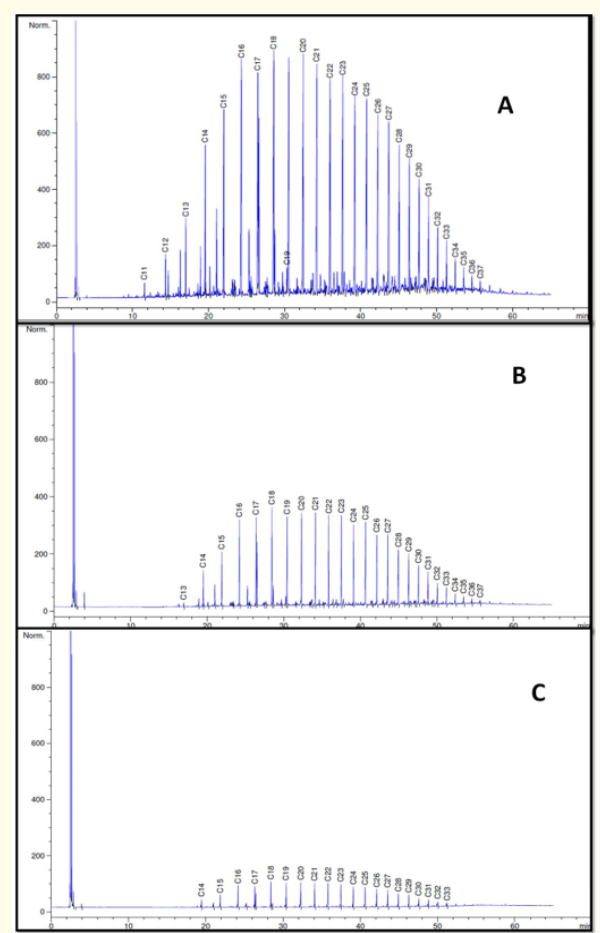

Figure 3: GC chromatograph showing the presence of aliphatic hydrocarbons (a) 0 day, (b) 5 days after treatment with TER-4 bacterial strain and (c) 5 days after treatment with TER-7 bacterial strain.

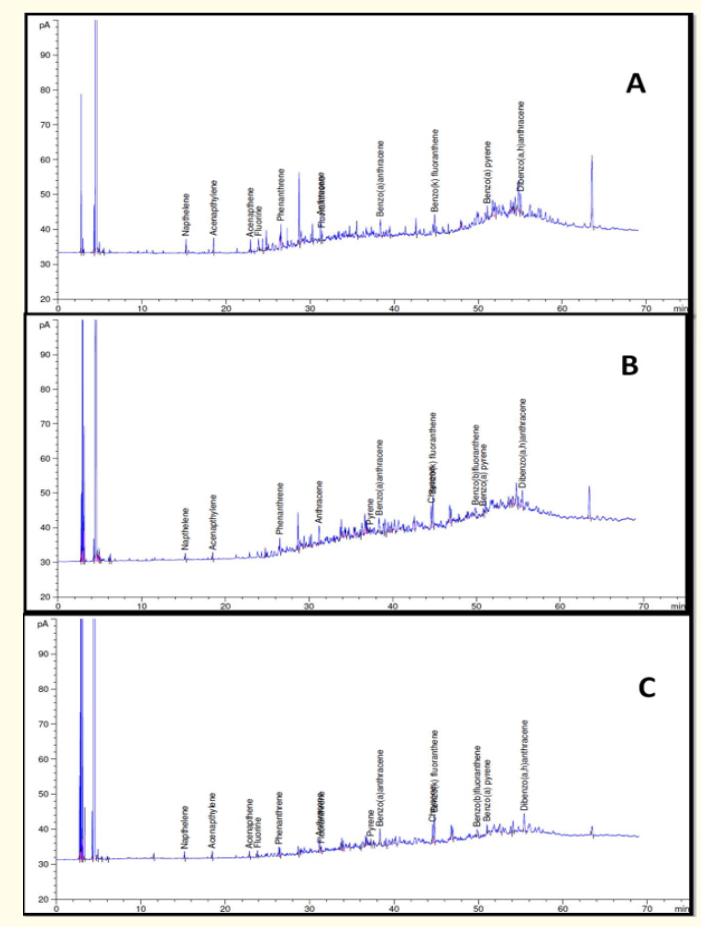

Figure 4: GC chromatograph showing the presence of aromatic hydrocarbons (a) 0 day, (b) 5 days after treatment with TER-4 bacterial strain and (c) 5 days after treatment with TER-7 bacterial strain.

\section{Discussion}

Total eight bacterial isolates were isolated from the oily sludge samples collected from hydrocarbon contaminated sites of three refineries. All eight isolates were able to produce biosurfactant exhibited through surface tension reduction, emulsification activity in supernatant solution of isolate grown culture. Saisa-Ard., et al. [11] also reported that species belonging to Acinetobacter, Bacillus, Corynebacterium, Pseudomonas, Rhodococcus and Serratia are the most widely reported genera for biosurfactant producing bacteria from hydrocarbon contaminated terrestrial or marine sites. Two isolates TER-7 and TER-4 were shown the significant reduction in surface tension activity (26.66 and $30.33 \mathrm{dy} / \mathrm{cm}$ ) as compared to all other isolates. E24 activity was observed in the range of $23 \%$ to $79 \%$. Highest significant emulsification activity was observed in the supernatant solution of isolate TER-7 (79\%) in comparison to remaining isolates. All eight isolate were capable of reducing total petroleum hydrocarbon of crude oil in rage of 52.66-92.00\%. Significantly highest TPH reduction was shown by the TER-4 (92\%) and TER-7 (90.66\%). Both isolates TER-4 and 7 were capable to degrade aliphatic hydrocarbon compounds C11-C37, Minif., et al. [12] also reported the degradation of aliphatic fraction of $1 \%$ crude oil from bacterial isolates of different genera in range of $96.20 \%$ - 93.30\%, which is in accordance of the findings of present study. Aromatic hydrocarbons like napthelene, acenapthylene, acenapthene, fluorine, phenanthrene, anthracene, flouranthrene, benzo(a) anthracene, bnzo (k) fluoranthene and dibenzo (a, h) anthracene were degraded by TER-4 and 7 isolates. Kumari., et al. [13] 2018) also reported degradation of a mixture of aromatic compounds directly in the crude oil by microbial consortia. The degradation of aromatic and aliphatic compounds might be due to biosurfactant produced by the isolates because the application of biosurfactants has been proclaimed by Marchant and Banat [14], Kavitha., et al. [15] and Tahseen., et al. [16] to enhance hydrocarbon bioavailability which increases microbial biodegradation rate.

Biosurfactants are produced by diverse microorganisms having structures of different chemical and surface properties [17]. Microorganisms like Pseudomonas, Acinetobacter, Bacillus, Brevibacterium, Clostridium, Rhodococcus, Thiobacillus, Leuconostoc, Citrobacter, Candida, Corynebacterium, Penicillium, Ustilago, Aspergillus, Saccharomyces, Enterobacter, Paenibacillus and Lactobacillus are capable in producing different kinds of biosurfactant of low to high molecular weight [18-20]. The different types of biosurfactants includes glycolipids, lipopeptides, polysaccharide-protein complexes, flavolipid, phospholipids, fatty acids, polymeric surfactants and lipids $[17,21]$. Biosurfactant possesses the exceptional quality of decreasing the surface tension between two miscible or immiscible liquids, block hydrogen bonding and increase hydrophilic/hydrophobic interactions owing to cell surface hydrophobicity [22-23]. Biosurfactants are gaining importance in hydrocarbon bioremedia- 
tion, microbial enhanced oil recovery, and petrochemicals due to its biodegradation properties, substrate specificity, diverse functions, and rapid controlled inactivation [24-25] (Janek., et al. 2010; Lima., et al. 2011).

\section{Conclusion}

Oil refineries contributes to hydrocarbon pollution in soil and water. Bioremediation through biosurfactant producing bacterial isolates has been found to degrade crude oil significantly in a ecofriendly manner. Bioremediation of oil contaminated sites can be restored to natural condition by exploiting the biosurfactant producing ability of bacterial isolates from oily sludge. The potent hydrocarbon degrader obtained from present study, require to elucidate further field scale studies to utilize for treatment of oil contaminated sites.

\section{Acknowledgements}

The Authors would like to thank the The Energy and Resources Institute (TERI), New Delhi, India for providing the facilities needed to conduct this research.

\section{Conflict of Interest}

There is no conflict of interest.

\section{Bibliography}

1. Bhattacharya D., et al. "Evaluation of genetic diversity among Pseudomonas citronellolis strains isolated from oily sludge contaminated sites". Applied and Environmental Microbiology 69 (2003): 1431-1441.

2. Mandal AK., et al. "Bioremediation: an environment friendly sustainable biotechnological solution for remediation of petroleum hydrocarbon contaminated waste". International Journal of Research in Engineering, IT and Social Sciences 2.8 (2012): 1-18.

3. Xia W., et al. "Biosurfactant produced by novel Pseudomonas sp. WJ6 with biodegradation of n-alkanes and polycyclic aromatic hydrocarbons". Journal of Hazardous Materials 276 (2014): 489-498.

4. Mohan PK., et al. "Biokinetics of biodegradability of surfactants under aerobic, anoxic and anaerobic conditions". Water Research 40 (2006): 533-540.

5. Mulligan CN. "Environmental applications for biosurfactants". Environmental Pollution 133.2 (2005): 183-198.

6. Lal B and Khanna S. "Degradation of crude oil by Acinetobacter calcoaceticus and Alcaligenes odorans". Journal of Applied Bacteriology 81 (1996): 355-362.
7. Bodour AA and Miller-Maier R. "Application of a modified drops collapse technique for surfactant quntitation and screening of biosurfactant producing microorganisms". Journal of Microbiological Methods 32 (1998): 273-280.

8. Cooper DG and Goldenberg BG. "Surface-Active agents from two Bacillus species". Applied and Environmental Microbiology 53 (1987): 224-229.

9. Mishra Sanjeet., et al. "Evaluation of Inoculum Addition To Stimulate In Situ Bioremediation of Oily-Sludge-Contaminated Soil". Applied and Environmental Microbiology 67.4 (2011): 1675-1681.

10. Luque de Castro MD and Priego-Capote F. "Soxhlet extraction: past and present panacea". Journal of Chromatography A 1217 (2010): 2383-2389.

11. Saisa-Ard K., et al. "Isolation and characterization of biosurfactants producing bacteria isolated from palm oil industry and evaluation for biosurfactants production using low-cost substrates". Journal of Chemical Technology and Biotechnology 94 (2013): 275-284.

12. Mnif S., et al. "Simultaneous hydrocarbon degradation and biosurfactant production by oilfield selected bacteria". Journal of Applied Microbiology 111(2011): 525-536.

13. Kumari S., et al. "Improved polycyclic aromatic hydrocarbon degradation in a crude oil by individual and a consortium of bacteria". Bioresource Technology 254 (2018): 174-179.

14. Marchant R and Banat IM. "Microbial biosurfactants: challenges and opportunities for future exploitation". Trends in Biotechnology 30 (2012): 558-565.

15. Kavitha V., et al. "Microbial biosurfactant mediated removal and/or solubilization of crude oil contamination from soil and aqueous phase: an approach with Bacillus licheniformis MTCC 5514". International Biodeterioration and Biodegradation 94 (2014): 24-30.

16. Tahseen R., et al. "Rhamnolipids and nutrients boost remediation of crude oil-contaminated soil by enhancing bacterial colonization and metabolic activities". International Biodeterioration and Biodegradation 115 (2016): 192-198.

17. Martins PC and Martins VG. "Biosurfactant production from industrial wastes with potential remove of insoluble paint". International Biodeterioration and Biodegradation 127 (2018): 10-16. 
18. Li J., et al. "Production and characteristics of biosurfactant produced by Bacillus pseudomycoides BS6 utilizing soybean oil waste". International Biodeterioration and Biodegradation 112 (2016): 72-79.

19. Shekhar S., et al. "Biosurfactant producing microbes and their potential applications: a review". Critical Reviews in Environmental Science and Technology 45 (2015): 1522-1554.

20. Jimoh AA and Lin J. "Production and characterization of lipopeptide biosurfactant producing Paenibacillus sp. D9 and its biodegradation of diesel fuel". International Journal of Environmental Science and Technology 16 (2019): 4143-4158.

21. De Franca IWL., et al. "Production of a biosurfactant by Bacillus subtilis ICA56 aiming bioremediation of impacted soils". Catalysis Today 255 (2015): 10-15.

22. Anyanwu C., et al. "Lipopeptide biosurfactant production by Serratia marcescens NSK-1 strain isolated from petroleumcontaminated soil". Journal of Applied Sciences Research 7 (2011): 79-87.

23. Darvishi P., et al. "Biosurfactant production under xtreme environmental conditions by an efficient microbial consortium, ERCPPI-2". Colloids Surfaces B Biointerfaces 84 (2011): 292300.

24. Janek T., et al. "Isolation and characterization of two new lipopeptide biosurfactants produced by Pseudomonas fluorescens BD5 isolated from water from the Arctic Archipelago of Svalbard". Bioresource Technology 101 (2011): 6118-6123.

25. Lima TM., et al. "Evaluation of bacterial surfactant toxicity towards petroleum degrading microorganisms". Bioresource Technology 102 (2011): 2957-2964.

\section{Assets from publication with us}

- Prompt Acknowledgement after receiving the article

- Thorough Double blinded peer review

- Rapid Publication

- Issue of Publication Certificate

- High visibility of your Published work

Website: https://www.actascientific.com/

Submit Article: https://www.actascientific.com/submission.php Email us: editor@actascientific.com

Contact us: +919182824667 